\title{
Introduction to Studies on Pre-Capitalist Modes of Production: Debates, Controversies and Lines of Argument
}

\author{
Laura da Graca and Andrea Zingarelli
}

This book analyses a variety of historical problems related to pre-capitalist societies and explores both the concept and the range of modes of production arising from the writings of Marx and Engels ${ }^{1}$ and subsequent Marxist elaborations. There are differing assessments of the Marxist tradition on pre-capitalist modes of production, which reflects the debate within historical materialism with regard to the potential or the inconsistencies of some of the categories proposed by Marx. The critique of these categories, or the perception that they are insufficient, has led to the elaboration of new concepts such as the domestic mode of production proposed by Claude Meillassoux aimed at the analysis of agrarian lineage societies, ${ }^{2}$ Marshall Sahlins's homonymous concept covering hunter-gatherer societies, ${ }^{3}$ or Chris Wickham's recently proposed peasant mode of production geared to the analysis of agrarian societies without systematic surplus extraction. ${ }^{4}$ These categories attempt a more precise structural study of different types of societies that are usually bundled into the concept of the primitive communist mode. The latter is for many the only non-exploitative mode of production proposed by Marx, whose evolutionary variations would express transitional modes such as the ancient and Germanic modes; other perspectives consider these structures independently, which widens the scope of non-exploitative modes of production; in the case of the Germanic mode, the varying interpretations of its contents highlight either the communal or the private component. ${ }^{5}$ The revision of the Formen has also given rise to an

1 Mainly, Marx and Engels 1965; Marx 1964, 1977a, 1977b and 1979. On the evolution of the ideas held by Marx and Engels regarding pre-capitalist societies and the successive reformulations starting with The German Ideology and up to writings subsequent to the Formen, see Godelier 1970, pp. 14-142.

2 Meillassoux 1991.

3 Sahlins 1972.

4 Wickham 2005, esp. pp. 535-50. The whole issue of the review Historical Materialism:Research in Critical Marxist Theory, volume 19(1), from 2011 is devoted to the analysis of this work.

5 The Germanic mode has been neglected according to Moseley and Wallerstein 1978. Maurice 
intense debate on the viability of the concept of the Asiatic mode of production and its substitution for the tributary mode proposed by Samir Amin ${ }^{6}$ and later re-elaborated by John Haldon as the universal mode of pre-capitalist class societies based on the extraction of rents or tribute, of which feudalism would be an institutional variant. ${ }^{7}$ Another perspective emphasises the singularity of the feudal mode of production, characterised by its specific form of coercion and private appropriation of rents. ${ }^{8}$ Moreover, the study of ancient societies has posed the problem of the evolution of the ancient mode toward exploitative forms; ${ }^{9}$ this evolution would be expressed not only in the development of slavery in those societies - systematised in the concept of the slave mode of production - but also in the development of exploitation through taxation; ${ }^{10}$ from this perspective, the exploitative phase of the ancient mode has been understood as a subtype of the tributary mode, considering in this case the centrality of taxation in contrast to the private extraction of rents. ${ }^{11}$

The most important debates and arguments regarding the mode of production and pre-capitalist modes of production took place between the 1960 and the 1980s, mainly in the 1970s, which witnessed a remarkable effort of compilation and publication in Latin America, ${ }^{12}$ the joint work published by Harold Wolpe, ${ }^{13}$ the work of systematisation by Barry Hindess and Paul Hirst ${ }^{14}$ and

Bloch 2004, pp. $35 \mathrm{ff}$, remarks on the lack of relevance of the Germanic mode in Marxist studies, and he attributes it to the weakness of the sources used by Marx in his elaboration of the concept. Among others, Godelier 1964 considers the Germanic mode in its own terms; Macfarlane 2002 stresses the centrality of private property in the Germanic mode; however, Wickham 1994a, pp. 29-30 stresses the communal component.

$6 \quad$ Amin 1976.

$7 \quad$ Haldon 1993, and 1995 .

8 Anderson 1979, pp. $402 \mathrm{ff}$.

9 On the ancient mode of production, see Hindess and Hirst 1975, pp. 79 ff.; on its evolution toward the appearance of classes, see Padgug 1975.

$10 \quad$ Haldon 1993, pp. $90 \mathrm{ff}$.

11 Wickham 1994a.

12 For example, in 1978 Gebran published a volume titled Conceito de modo de produção compiling earlier publications; see also Sempat Assadourian et al. 1973.

13 Wolpe 1980, with the participation of Banaji, Dupré and Rey, Lublinskaya, Meillassoux, Morris and Quijano Obregón.

14 Hindess and Hirst 1975 encompasses both the general concept of mode of production and the study of the concepts of primitive-communist, ancient, slave, feudal and Asiatic modes of production, without analysing concrete social formations; it is based on Marxist theory and attempts to avoid the generalisation into a series of historical societies in the sense of Weberian ideal types: Hindess and Hirst 1975, p. 2. 
the joint discussions on the Asiatic, slave and feudal modes of production that we will discuss below. Discussions on the study of non-European societies in terms of mode of production and their articulation with other systems also developed during this period, especially after the work of Pierre-Philippe Rey, Harold Wolpe and Claude Meillassoux provided a framework for their analysis. ${ }^{15}$ In subsequent decades, Marxist historians addressed specific aspects of the modes of production present in the writings of Marx and Engels, while abandoning in part the joint discussion and to some extent the comparative discussion of the concept of mode of production. At the same time, however, new modes of production not present in the original Marxist tradition were proposed. In that regard, among the works of the last few decades worthy of note are the joint publications on the concept of the tributary mode of production ${ }^{16}$ and the work of Jairus Banaji on pre-capitalist modes familiar to the Marxist tradition such as the Asiatic mode and recently formulated ones such as the peasant mode. ${ }^{17}$

The notion of Asiatic mode of production is one of the most controversial ones in Marxist historiography. ${ }^{18}$ This is due to its scant textual presence in Marxist writings and to the fact that it was associated both with ancient nascent states and with contemporary Eastern societies (such as India), which preserved the statism of the communities and had not yet experienced capitalism. In the Soviet Union during the 1930s, the issue of Asiatic stagnation was especially discussed (particularly with regard to China but clearly with Russia in mind), giving rise to the 'feudal interpretation' and the 'slavery interpretation'.19 At that time, the notion of Asiatic mode of production was suppressed for political and academic purposes, and the notion became anti-Marxist. In subsequent decades, there were attempts to revive the notion such as Karl Wittfogel's Oriental Despotism, ${ }^{20}$ which highlights the hydraulic character of societies and analyses despotism in bureaucratic-administrative terms, thus simplifying the problem of the Asiatic mode of production. For its part, the remarkable work of Childe does not reject the notion of Asiatic mode of production, and although his study on the origin of civilisation takes into account irrigation

15 See, for example, Harries 1985, Freund 1985, and Geschiere 1985; about Latin America, see Goodman 1977, Soiffer and Howe 1982, and Scott 1976.

16 Haldon et al. 1998, and Haldon and García Mac Gaw 2003.

17 Banaji 2010. This work collects thirty years' worth of essays and critical studies.

18 Krader 1975; Sawer 1977; O'Leary 1989, among others.

19 See Sofri 1969 and Dunn 1982.

$20 \quad$ Wittfogel 1981. 
control, he considers it to be one among a number of other factors. ${ }^{21}$ During the 1960 os the notion of Asiatic mode of production was addressed once more in a more reflexive vein. ${ }^{22}$ The debate is acknowledged as existing in English Marxist academic circles, in France, and also in the Soviet Union. The department of Asiatic and African studies of the Centre d' etudes et de recherches marxistes developed research on said notion, and La Pensée published various articles and a special booklet on the concept as it applies to the early class societies. ${ }^{23}$ Eventually, the concept of Asiatic mode of production was revisited in studies on pre-Columbian America, black Africa and China, thus exceeding the original geographic nucleus formulated by Marx, which led to the proposal of other denominations such as communal-exploitative mode or despotic village mode. ${ }^{24}$ At the same time, although Hobsbawm's 1964 introduction to the first English edition of the Formen does not address the Asiatic mode of production too thoroughly, it does posit that this mode disappeared from the systematic treatments in the later work of Engels (Anti-Dühring and The Origins of the Fam$i l y$ ) because he had changed his mind on the issue of primitive communities. He also suggests that later Marx and Engels had considered a historical stage of communal disintegration in which different types of dominant classes would have emerged. ${ }^{25}$ This type of anti-Asiatic mode of production position is based on the fact that it ceased being included in the arguments found in the later works of Marx and Engels. Quite to the contrary, Maurice Godelier ${ }^{26}$ picks up where Marx left off in the Formen when acknowledging the unity of contradictory elements in the exploitation of particular communities, village communities exhibiting the ultimate form of classless society, by a minority or superior community understood as a nascent form of class society. Godelier's proposal makes this structural contradiction viable and extends it to different societies. The combination between village communities and the state described by Marx in the Formen as Asiatic despotism is held by Samir Amin ${ }^{27}$ among others - although this author proposes significant nuances and calls it the tributary mode - and by Guy Dhoquois, ${ }^{28}$ for whom there would exist different degrees in the contradictions between productive forces and social relations of produc-

\footnotetext{
21 Childe 1936.

22 Also to reject it, as in Shapiro 1962, p. 284.

23 Ruiz Rodríguez 1979.

24 Chesneaux 1964.

25 Marx 1964, pp. 51-2.

26 Godelier 1971, 1978b.

27 Amin 1976.

28 Dhoquois 1971, pp. $67 \mathrm{ff}$.
} 
tion, which would allow for distinct variants: the Asiatic mode of production, the sub-Asiatic mode of production, and the para-Asiatic mode of production.

A majority of the anti-Asiatic mode of production positions (Wickham, Anderson, Hindess and Hirst, Banaji $)^{29}$ underscore that the concept is invalid, especially the coexistence of self-sufficient village communities and a state ${ }^{30}$ that has to contain classes, and they also question the absence of private property of land in some of the societies to which the concept is applied. According to Wickham, ${ }^{31}$ the survival of the Asiatic states is due to the persisting dominance of the tributary mode in a variety of social formations in spite of the continuous weakening effected by feudal relations. On the other hand, Banaji's characterisation of Asiatic regimes ${ }^{32}$ places them in the tributary rather than the feudal mode, but he establishes a difference between tax and rent and between European feudalism and the Asiatic systems. Hindess and Hirst, ${ }^{33}$ as well as Anderson, emphasise that it is impossible to conceive that a state which imposes forms of production will not give rise to classes, although they focus their critique on the tax/rent couple, which would not correspond to an exploitative system of appropriation. On the other hand, those who hold the validity of the Asiatic mode of production, like Cardoso ${ }^{34}$ or O'Leary, ${ }^{35}$ are attached to Marx's postulates, even when they are critical, and they question the idea that Marx and Engels abandoned the notion of Asiatic mode of production in their later works.

The discussion surrounding the slave mode of production, which Stalin dogmatically held was a necessary stage in the development of societies, is focused on the problem of establishing the role of slavery as a relation of production and whether or not it constitutes the productive foundation of the societies in which we verify the existence of slaves. ${ }^{36}$ Thus, the publications of the period

29 Wickham 1994b; Anderson 1979, esp. pp. 484ff.; Hindess and Hirst 1975, esp. pp. $198 \mathrm{ff}$; Banaji 2010, pp. $17 \mathrm{ff}$.

30 Thus postulated from its formulation in the Formen and in the article Marx wrote for the New York Daily Tribune in 1853, Marx 1979, pp. 125-9.

32 Banaji 2010.

33 Hindess and Hirst 1975.

34 Cardoso 1990.

35 O'Leary 1989.

36 Prieto et al. 1986, with translations of articles previously published in specialised publications: Petit 1972, Vittinghoff 196o, Sereni 1973b, Parain 1963, Guenther and Schrot 1953, among others. Giardina and Schiavone 1981 gathers the contributions of a colloquy celebrated at the Gramsci Institute in Pisa. 
question the idea of the slave mode as the only analytical tool for the GrecoLatin world, highlighting the problem of the coexistence of slavery with other forms of exploitation and the study of the whole based on the concept of social formation. ${ }^{37}$ The variety of occupations held by slaves also poses a problem for considering them as a class. The work of Ste. Croix is crucial for addressing these questions, since he understands class as the collective social expression of the fact of exploitation, and the slave mode of production as the dominant mode in ancient societies in that it is the pre-eminent manner in which the proprietary class extracts surplus. This criterion, rather than the manner in which product is obtained - in the ancient world it came mainly from subsistence peasants - is for the author what determines the dominance of a mode of production in a given social formation..$^{38}$ Perry Anderson also postulates the dominance of the slave mode of production in the Classical world (specifically, for Greece in the fifth and fourth centuries BC and Rome from the second century $\mathrm{BC}$ to the second century $\mathrm{AD}) .{ }^{39}$ The concept of slave mode of production has been systematised by Hindess and Hirst, who assert its independent statute based on the theoretical possibility to identify productive forces and specific relations of production and of property, whose basic traits could be summarised as the total separation of direct producers from the means of production, the effective possession by non-producers of all the factors of production, the total dependence on non-producers for the launching of the productive process, the appropriation by non-producers of the totality of what is produced by slaves and the treatment of the latter as fixed capital, which explains the need to constantly supervise them and the predominance of simple cooperation. Hindess and Hirst distinguish the slave mode from the simple possession of slaves, seeing as the former implies that slave labour is the foundation of production, which presupposes the development of private property, exchange, and a necessary connection with specific superstructural aspects such as a legal form of slave property and ideological practices adapted to the contradiction implied by the situation of the slave as both a means of production and a direct producer. Although in theory the slave mode of production does not require the existence of other modes of production, the historical rule has been its

Parain et al. 1975 gathers contributions by Parain, Kolendo, Staerman, Annequin, ClavelLévêque and Favory, among others. See also Marxism and the Classics, special issue of Arethusa, a collection of articles expressing a general revalorisation of the Formen, especially Konstan 1975 and Padgug 1975.

39 Anderson 1996, pp. 18-28. 
coexistence with other systems, as exemplified by the ancient world and the American case. ${ }^{40}$ The articulation of slavery with other modes of production is an essential trait for Claude Meillassoux, who addresses the problem from the perspective of the social reproduction, relying partially on the societies that slaves hail from, a circumstance that increases the benefit of slaveholders and discourages breeding. ${ }^{41}$ Lastly, the concept of slave mode has been discussed in the context of the debate over the transition to feudalism, which at one time centred on the causes of the decline of slavery, a question that stimulated discussions on the profitability of the system and the role of class struggle. ${ }^{42}$ Nowadays the debate over the transition to feudalism has shifted to the issues surrounding social formation, which includes other forms of exploitation such as colonate and taxation, and the emergence of non-exploitative modes, ${ }^{43}$ the conversion of slaves into tenants being only one of the shifts to consider in the study of the transition toward the full dominance of the feudal mode of production.

The concept of feudal mode of production became widespread with the pioneering work of Maurice Dobb and Eugene A. Kosminsky, who streamlined its contents to the extraction of rent through legal-political means. ${ }^{44}$ The debate around this concept, however, developed later. The most significant joint publication emerged from a colloquium on classical feudalism and the pre-colonial Maghreb with the participation of, among others, Charles Parain, Pierre Vilar and Renè Gallissot, which brought forth the idea of feudalism as a social formation whose nucleus is the feudal mode of production identified with a basic social relation that does not necessarily imply the presence of a fief; ${ }^{45}$ from the consideration of the superstructure as a secondary element

$40 \quad$ Hindess and Hirst 1975, pp. 109-77, esp. pp. 125 ff.

41 Meillassoux reiterates this argument with regard to the articulation of capitalism with the domestic economies that provide temporary labourers whose reproduction is not entirely paid by capital; he understands the problem in terms of a transference of value from one mode of production to another: Meillassoux 1992, part II.

Bloch, Finley et al. 1975. Dockés 1982 is still a valuable reference in what pertains to the structure of the slave villa and the forms assumed by class struggle; on the persistence of the slave mode of production during the Middle Ages, see Bonnassie 1985, which also summarises the debate on the decline of slavery. For a study on slavery in America that questions the argument of low profitability, see Stampp 1956, ch. 9. A review of the debate over this and other issues related to the slave mode can be found in Cardoso 1973.

43 Wickham 1994a.

44 Dobb 1946, ch. 2, and Kosminsky 1956, preface.

45 Centre d'Études et de Recherches Marxistes 1972. 
emerges the tendency to extend the concept of feudalism to extra-European societies that did not experience the political configuration derived from vassalage and fiefdom. ${ }^{46}$ Contrary to this tendency, Perry Anderson asserts that the superstructural elements, to the extent that they shape the specific type of coercion required for the extraction of surplus, constitute not only an essential component of pre-capitalist modes of production but serve to distinguish them from one another. At the same time, in Anderson's view it is of crucial importance that only Western feudalism gave rise to capitalist relations, a circumstance he attributes to the fragmentation of sovereignty, which permitted the autonomous development of cities. ${ }^{47}$ Chris Wickham questions this perspective, proposing instead an analysis of Eastern empires as social formations in which feudal rents and tax coexist; the persistence of states that control the aristocracy of proprietors would express the strength, rather than the stagnation, of 'Asiatic' type societies, which would in turn challenge the singularity of Western dynamism. Adding nuance to earlier statements, Wickham concludes that the private or public extraction of surplus from peasant producers does not substantiate the existence of different modes of production. ${ }^{48}$ This tallies with the proposal to limit the coercive extraction of rent or tribute to just one mode of production, allowing its denomination as feudal or tributary to be a matter of terminology. ${ }^{49}$ However, for some authors the study of tributary societies reveals the existence of singular structural features such as, among others, a state domination that preserves the cohesion of peasant communities, as opposed to the nature of the feudal relation, which presupposes the dissolution of those communities due to the extension of personal dependence. In this regard, Eduardo Manzano Moreno has posited the need for structural studies to consider not only the nucleus of the productive relation but also the specific form in which control over people and means of production is exerted. ${ }^{50} \mathrm{In}$ opposition to the universality of a feudal or tributary mode, other authors have asserted that historical contextualisation is central when it comes to modes of production $^{51}$ as well as the essential character of political elements and their

46 For example, for feudalism in Byzantium, see Ostrogorsky et al. 1974.

47 Anderson 1979, conclusions, and 1996, pp. 147-53 and pp. 182-96.

48 Wickham 1994b. Byres and Mukhia 1986 compiles contributions to the debate on the categorisation of Eastern forms as feudal. On this debate in the Journal of Peasant Studies see Bernstein and Byres 2001, pp. 9-10.

Wickham 2008, n. 5 .

50 Manzano Moreno 1998.

51 Banaji 2010, pp. 183-5 and 212-14. Also Banaji 2011, pp. 111-12. 
privatisation in the feudal mode of production, which creates the possibility of autonomous processes of accumulation. ${ }^{52}$ Beyond this debate, the place of political forms in pre-capitalist societies has been underscored by Marxist theorists whose starting point is the absence of a split between the political and the economic spheres that characterises the period before the full dominance of the capital relation: Cesare Luporini, for example, notes the absence of economic mechanisms analogous to the productive reinvestment of surplus value, a circumstance that demands the constant recreation of political forms for the reproduction of the exploitative relation; ${ }^{53}$ Georg Lukács stresses that legal-political elements are inseparable from the relations of production, which thwarts the development of class consciousness in pre-capitalist societies. ${ }^{54}$

The use of the term feudalism in reference to Eastern societies has been rejected by historians specialising in Muslim studies, ${ }^{55}$ an opinion cited by Ludolf Kuchenbuch and Bernd Michael, who systematise the concept of feudal mode of production and circumscribe it to Western Europe. ${ }^{56}$ With regard to the dynamics of the system, these authors subscribe to the scheme proposed by Guy Bois, which is based on a concept of feudal mode of production that assigns to small peasant production analytical pre-eminence over lordship. ${ }^{57}$

It is worth noting the controversy surrounding the transition from feudalism to capitalism initiated in the 1940s with the studies by Rodney Hilton, Eugene A. Kosminsky and Maurice Dobb, who take up Lenin's point that the enriched sectors of the peasantry - as they liberate themselves from serfdom - tend to become simple commodity producers and later turn into capitalists..$^{58}$ During the 1950s, Marxist authors focused on determining the changes that occurred during the fourteenth and fifteenth centuries. The debate zeroed in either on the primacy of endogenous factors such as the relation of exploitation and the development of peasant social differentiation - expressing the first road proposed by Marx ('the really revolutionary way') which is centred on the trans-

\footnotetext{
$52 \quad$ Monsalvo Antón 1986; Astarita 1994, and 2003.

53 Luporini 1981.

$54 \quad$ Lukács 1967.

55 Cahen 1963; Rodinson 1978, ch. 3; Guichard 1984; Manzano Moreno 1998; Chalmeta 1973; Barceló 1994.

$56 \quad$ Kuchenbuch and Michael 1977 refer to Cahen and Rodinson.

57 Bois 1984 .

$5^{8} \quad$ Hilton 1947; Dobb 1946, ch. 2; Kosminsky 1956.
} 
formation of the economy of direct producers ${ }^{59}$ - or, conversely, on influences that are external to the system, such as the actions of commercial capital, ${ }^{60} \mathrm{a}$ factor that some consider undermining and others perceive as functional to the reproduction of feudalism. ${ }^{61}$ The debate was renewed in the 1970 s with Robert Brenner's proposal, which, although initially meant to counter the approaches centred on demography and trade, nonetheless provided a new model for interpretation that was remarkably well received in Marxist academic circles. In opposition to British Marxist historians, Brenner rejects the protagonism of direct producers and small holdings, which he considers subject to rules of reproduction directed toward subsistence rather than profit maximisation; instead, in his view the agrarian transformation can be attributed to the large-scale leases promoted by the lord, the formation of which - an English singularity Brenner attributes to the failure of the peasantry to consolidate its property rights; the author posits that the loss of direct access to subsistence brings about an economic behavioural pattern that is functional to the requirements of capitalist development. ${ }^{62}$ Brenner combines the methodological individualism of liberalism with the Marxist tradition according to which the increase in productivity occurs in large holdings and presupposes a process of expropriation. Brenner's thesis has been questioned within the framework of other debates, such as the studies on the productivity of small and medium holdings, ${ }^{63}$ on the

59 Dobb 1946, ch. 2.

6o Sweezy 1976. The Dobb-Sweezy debate influences the discussion on modes of production in Latin America, which counts among its central points the pre-eminence of the sphere of circulation versus the pre-eminence of the sphere of production and the idea of productive stagnation as an essential trait of feudalism as opposed to the dynamism of commercial capital; regarding this, see Laclau 1973.

61 Hilton $1985 \mathrm{~b}$ insists on the non-revolutionary character of urban sectors of the population whose income depends on the success of seigneurial exploitation; the thesis is adopted by Kuchenbuch and Michael 1977.

62 Brenner 1976. Aston and Philpin 1985 collect the debate developed in Past and Present in the 1970s with the participation of authors who advocate the demographic approach. In Brenner 2000 the author brings his thesis outside of England; the dispossession from means of subsistence and the change in mentality are no longer related to class struggle but are related to a natural process of deterioration of the soil. Wood 1999, and Comninel 2000 follow Brenner's general scheme, although they refer to historical conditions specific to England in order to explain the formation of large properties.

63 For example, Allen 1992 questions the premise that attributes the increase in productivity to enclosures; instead, he detects a trend toward development in medium holdings that remain in the open field and are managed by yeomen. Hoffman 1996, ch. 4 and 5 also proves the possibility to increase productivity in small holdings. 
conditions of transmission and possibility to expropriate the copyhold, ${ }^{64}$ and in general by empirical evidence, which tempers the importance of seigneurial leases and reveals the ambivalent profiles of large farmers, who had emerged from the stratum of enriched peasants. ${ }^{65}$

In contrast with the idea - proposed by Marx in the Formen and further developed with various nuances by scholars of the transition to capitalism that the relation of capital entails the dissolution of earlier forms of property, ${ }^{66}$ the thesis put forward by Guy Bois, albeit incorporating elements that are extraneous to Marxist analysis, restates the terms of the problem by associating the emergence of capitalist relations to the laws governing the functioning of the feudal mode of production. ${ }^{67}$ This matrix has been developed by authors who link the origin of the capital relation with specific traits of feudalism and its dynamic, which unfold independently of regular economic and demographic features. ${ }^{68}$

Lastly, the debate on the transition to capitalism has spawned works of synthesis that reflect either the different interpretations - Marxist and nonMarxist ones which we have not addressed in the present work - or the discussions surrounding all the stages of the process. ${ }^{69}$

64 This line of research, whose importance for English agrarian history had already been noted by Tawney 1912, pp. $287 \mathrm{ff}$., finds further development in the debate on the land market, a problem that includes the analysis of the legal conditions for land tenancy. Among others, Whittle 2000, pp. 74-84, and Hoyle 1990 question the view that copyhold could be easily expropriated.

65 In this respect Dyer 1994 offers a sufficient approach.

66 Brenner presents the more extreme formulation of this perspective, which appears in more nuanced forms among authors who advocate the gradual development of commodity production; there are differences among these latter authors too; Kosminsky, for example, has insisted that 'capitalist relations are gradually generated within the feudal mode of production', Kosminsky 1956, preface, p. xiii.

67 Bois 1984

68 Astarita 2005 , ch. 5, explains the emergence of wage-earners due to a number of factors inherent to the system, such as the seigneurial appropriation of space, a phenomenon derived from the forms of property; da Graca 2009 associates the conditions of possibility for social differentiation to specific structures of coercion that imply distinct degrees of peasant autonomy and seigneurial intervention.

69 Some useful references are Kaye 1984, which includes an analysis of the period addressed by Hobsbawm and Thompson; Wood 1999, in line with Brenner, and Rigby 1995, ch. 2 and 3 ; the author combines a didactic formulation of the problems under analysis with a disenchantment with Marxism, which at times undermines his perspectives. 
Through the study of various problems, the contributions included in this book deal with the concepts of primitive-communist, Asiatic, Germanic, domestic, peasant, ancient, slave, tributary, ancient tributary, feudal and capitalist modes of production.

In general, the concept of mode of production is understood in the present work either as the social configuration corresponding to certain relations of production more or less associated to a certain development of productive forces (an aspect deemed to be less relevant or subordinated to relations of production), or as a combination of productive forces and relations of production which express themselves by means of property relations. Some authors derive modes of production from the relation of real appropriation or nonappropriation of the means of production by direct producers - which determines the basic form of surplus extraction - thus identifying modes of production with forms of labour exploitation, as in the perspectives held by Chris Wickham and John Haldon; the link of producers with the means of production as a central element for the categorisation of a mode of production - as posited by Marx in his writings on the evolution of land rent - supplies the basis for Carlos García Mac Gaw's questioning of the concept of slave mode of production as it has been used by historians. From the perspective of some of the authors who contributed to this book, property relations encompass the specific form of surplus appropriation, which results in a wider set of modes of production derived from the private or common appropriation of the conditions of production and the surplus. This approach, which follows the Formen more closely, attributes a differentiated dynamic to the mode of production. For example, Andrea Zingarelli underscores the collection of peasant rents by the state as a dominant mechanism and its imposition in pharaonic history; she posits that the state or state institutions (including religious institutions) are the main recipients of the surplus production of immediate producers: land rents are collected in the form of taxes. Thus, it is the state that confronts direct producers as a landowner, which results in the convergence of rent and tax, a question posed by Marx, and differentiates the Asiatic mode from other modes of production, because most of the property is in state hands (the superior community) and private property only exists as a secondary and non-pure form, and is even subordinated to state property in certain historical periods. Laura da Graca categorises the distinctions among different forms of property and the centrality of individual property, which she assigns to the Germanic mode of production. In her view, the peasant mode of production is to be understood in terms of the Germanic mode, applied to societies with a prevalence of allodial property and emancipation from kinship. The potential for social transformation brought about by the individual appropriation of the fruits of labour - explored by Marx and 
Engels in various works ${ }^{70}$ and analysed by scholars of the transition to capitalism $^{71}$ - is the condition of possibility for multiple developments that are not found in societies with other forms of property: from this perspective, Carlos Astarita links the origin of the medieval craftsman with the individual appropriation of the conditions of production, which is the common denominator both in the free peasant household of Germanic or peasant-based societies and of the household subject to rent under the feudal mode of production. In the contribution by Octavio Colombo, the feudal mode of production and the conditions it imposes on commodity production explain the inequivalence in the exchange whose functionality to processes of accumulation is also linked to the specific structure of property that allows for individual appropriation of benefits derived from the trade practices of wealthier villagers.

In most of the contributions, the analysis of one or more modes of production presupposes or implies the concept of social formation. The authors approach this concept with different criteria that have emerged from the debate over this analytical category within Marxist thought, which touches on the epistemological question related to the construction of the universal term. This debate - which deals with the problem of how to think a social whole - starts with the work of Lenin who, in the context of his controversy with Mikhailovsky's subjectivist interpretation (What the 'Friends of the People' Are and How They Fight the Social-Democrats), poses the question of what an economicsocial formation consists of. Lenin understands this category as the set of relations of production in their natural historical development. ${ }^{72}$ In view of the influence it exerted on later developments, Lenin's main contribution to the concept of social formation appears in The Development of Capitalism in Rus$\mathrm{sia}^{73}$ where he analyses the particular Russian social formation following the reform of 1861 with a view to characterising the social structure whose degree of differentiation is crucial in the definition of policies. The prevalence of capitalist relations in the country, empirically demonstrated by Lenin, implies the advance of commodity production over pre-existing forms, but also the partial validity of the latter forms; thus, the Russian social formation is a combination of different systems (capitalist relations, serfdom, communal structures) under the dominance of commodity production, which in turn tends to subordinate the other socio-productive structures by modifying their essential contents.

\footnotetext{
$70 \quad$ Marx 1964, pp. 75 ff., Marx 1989; Engels 1989, and 1987.

71 For example Kosminsky 1956, p. 207.

72 Lenin 1963, pp. 129-332.

73 Lenin 1964.
} 
The social formation is thus understood as a hierarchical totality rather than a simple combination. As suggested by Christine Glucksmann, the modification of persisting structures implies a theory of transition, and therein lies Lenin's main contribution. ${ }^{74}$ This conception rising from the analysis of the Russian economic-social regime is consistent with Lenin's earlier formulation according to which a social formation was the aggregate of all the relations of production in their processes of change; therefore, the concept of social formation is especially appropriate to the study of transitional social formations featuring a diversity of relations of production and social forces in a state of struggle, while it could be identified with the mode of production when said mode has full dominance.

Lenin's perspective is partially taken up by structuralism, which understands the social formation as the combination of modes of production in a specific articulation, with the dominant mode of production providing the general guidelines of the whole. This articulation presupposes superstructural elements - given that a social formation is a system of levels of the different modes of production, which are in turn integral systems of the various spheres (political, ideological, economic) - expressing the phenomenal aspect, the singularity of real societies. In the structuralist approach, the social formation, as a historically determined real-concrete object, is analytically distinct from the mode of production, considered as an abstract-formal object that does not exist in reality. ${ }^{75}$ This approach is questioned by Emilio Sereni, for whom the relationship between mode of production and social formation does not imply different levels of abstraction: Sereni understands the social formation as the unity of the different spheres and the conditions for their development, that is to say, as the totality of structural and superstructural elements in their historical progression; the mode of production would only express the economic aspect of the social formation, which in turn comprises all other social relations; thus, the analysis of a social formation is no less susceptible to theorisation than the mode of production, or is not confined to the purely empirical plane. ${ }^{76}$ Lenin's statements on the category of the social formation also provide a basis for this approach in that they suggest the inclusion of superstructural Marxista) and France (La Pensée) in which the traditions established by Althusser and Gramsci are discussed in conjunction. See Starcenbaum 2011, pp. 45-6. 
aspects and the idea of dynamism: in his review of the use of the expression in the work of Marx, Lenin refers to the social formation as a 'living thing' - therefore, a changing thing - in which the relations of production are the 'skeleton' that the analysis has to fill in with other components through the study of the superstructure and the 'actual social manifestation of class antagonism' ${ }^{77}$

In line with Sereni's arguments questioning the structuralist approach, the debate on the concept of social formation involves a critique of the identification of the categories of historical materialism with different levels of abstraction. Faced with this trend, some authors enhance the role of the conceptualisation of the mode of production as an empirically identifiable structure that must be developed through analysis rather than reduced to its essence; from this point of view, the social formation considered as a combination of structures is equally susceptible to theorisation. ${ }^{78}$ Another side of the debate suggests that the relationship between mode of production and social formation corresponds to the model and to specific historical manifestations respectively, and that the model should be understood as an elaboration for the purposes of interpretation, as Luporini puts it. ${ }^{79}$ Thus, for example, the development of the concept of capitalist mode of production as it appears in Capital - which Marx refers to as an 'ideal average' 80 - should guide the study of other societies, such as the Russian social formation, where it will confront empirical variations; the confrontation is possible because the model expresses the real and develops laws that govern its functioning; in this way the variants of the case in point can contribute to a reformulation or an enrichment of the theory, as in the case of the conditions for the genesis of capitalist relations, which according to Lenin's study on Russia would not entail the total dispossession of the means of production as had been posited by Marx starting with his study on England. ${ }^{81}$ According to Luporini, Lenin's work is an example of this approach to theory, which Lenin summed up in his statement that Capital cannot be regarded 'as anything more than an explanation of a particular social-economic formation', and never 'as some universally compulsory philosophical scheme of history' ${ }^{2}$

77 Lenin 1963.

78 Dhoquois 1973; Herzog 1973.

79 Luporini 1973a and 1973b; Labica 1973.

8o Regarding the meaning of this expression used by Marx, see Althusser's observations interpreting the 'ideal average' as a concept of the real rather than an abstract or empirical average in Althusser and Balibar 1970, Appendix: On the 'Ideal Average' and the forms of transition.

$81 \quad$ Lenin 1964.

$82 \quad$ Lenin 1963. 
To the extent that the model is conceived of or constructed as an ideal type in the Weberian sense instead of an 'ideal average' that can be identified with the deep inquiry into a particular case, it is not being confronted with eventual variants but with the complexity of the real. In this book, the above perspective is developed in John Haldon's contribution, which posits that a mode of production is an ideal type informing an essential nucleus that is common to a number of societies and constituted by a combination of relations of production and productive forces. The concept only illuminates the form of appropriating the surplus, not its specific mechanisms, which would correspond to the sphere of the social formation understood as the specific historical configuration of a specific mode of production where all the elements of the superstructure concur. This perspective affects the theory of social transformations because institutional forms determine the concrete manners of historical change, while the mode of production can only indicate the potential for this change to occur. Chris Wickham also addresses the levels of abstraction: the peasant mode, like every other mode of production, is for him an ideal type that appears in real societies in combination with other modes of production, which are understood on principle not as a set of determinations but as an essential nucleus of relations of production. In this case, he focuses on demonstrating the dominance of the peasant mode in social formations with developed aristocracies such as Norway; this dominance (as it is posited in the structuralist approach) expresses itself mainly in political practices, which, in the case analysed by the author, correspond to the basic guidelines of a peasant society. In a dissenting view, Laura da Graca systematises the concept of mode of production as a structure of reality, which allows for the consideration of a specific dynamic combining evolutionary trends derived from the form of property and social functioning; in contrast to Wickham's example, da Graca analyses a social formation dominated by feudalism; in line with Lenin's general argument, this dominance alters the contents of the other existing modes of production, which tend to become denaturalised. According to this perspective, a theory of social formation can be approached in terms of the subordination mechanisms of the dominant mode of production (as suggested by Godelier for other social formations). ${ }^{83}$

Carlos García Mac Gaw's contribution proves that the centrality of the concept of social formation extends beyond the analysis of transitional societies. The author provides examples of the variety of relations of production in which slaves participated in the Roman economy around the time of the Latin agro- 
nomists; this adds nuance to the relevance of the concept of slave mode of production in the characterisation of the whole and of its main socio-productive structure, the villa, inasmuch as this mode subsumes unto itself different relations of production; in his view, the slave mode of production (understood as only one relation of production, that in which the slave has no control over the productive process or its reproduction) cannot exist in history but in combination with other modes of production, which entails thinking of the social formation as a combination of structures. As an element of comparison between social formations, García Mac Gaw enhances the role of the articulation between modes of production (the subordination of slavery to central capitalism in the American case, and to the ancient tributary mode of production in the Roman case).

In his first formulations of the concept of social formation, Lenin's main goal was not to define an analytic category but to restore the pre-eminence of relations of production in the analysis of the historical process. The contributions by Carlos Astarita and Octavio Colombo show that this is not just a statement. Astarita's study explains the origin of trade specialisation as deriving from the relations of production and productive forces that characterise the period before the full configuration of the feudal mode, a period that must be understood as a social formation in which various structures coexisted, some in a nascent state and others trending toward dissolution, such as slavery; the trade - initially associated to the instruction of domestic slaves - finds an environment that favours its development in the households where fugitive slaves find shelter, and later in the holdings where they settle as rent-payers; this trajectory illustrates the formation of new social relations derived from already existing ones, whose potential becomes apparent in the analysis of the whole. Colombo's study assesses the functioning of the law of value in the context of social relations and productive forces, whose hierarchy in the analysis is given by the subordination of simple commodity production to a dominant mode of production, in this case, to feudalism; the mode of production provides the conditions in which exchange occurs, hindering the adaptation of price to value.

This book analyses historical processes that involve the problems posed by the transition from one mode of production to another, and most of the contributions address the problem of social transformation. García Mac Gaw detects an early trend toward indirect exploitation in the spread of the servus quasi colonus; according to Astarita, the same trend contributes to the fixation and development of trades in medieval times (and it also reflects the survival of slavery). The essays by Chris Wickham and Laura da Graca attempt to explain the transformation of peasant societies and the emergence or expansion of feudal relations; Wickham attributes this process to the accumulation of lands; 
da Graca relates it to the ability to dispose of property and the gradual alteration of the contents of social practice which nonetheless maintain the appearance of reciprocity. John Haldon's contribution also addresses this problem when among other examples related to the place of ideology in social reproduction he cites the belief systems that enable surplus extraction, which reflects the functioning of said systems as relations of production. Haldon questions the explanation that attributes structural transformation to the development of productive forces, to which he assigns a secondary role; to wit, he offers the example of Western Europe during the third and eighth centuries, where the development of techniques or patterns of consumption did not beget alterations in the relations of production. Although they do not deal explicitly with the effect of productive forces on relations of production, the contributions by Astarita and Colombo imply an approach to this problem from a different angle: Astarita stresses the qualitative aspect of the analysis of productive forces such as the creative skill of the craftsman, whose conditions for development are linked to the process of building new social relations; in Colombo's argument, the features of the productive forces determine the non-functioning of the law of value, which in turn favours the emergence of capitalist relations.

The different contributions are arranged according to an approximate chronological order and address the following periods: in the first chapter, Andrea Zingarelli focuses her argument on ancient Egypt; in the second chapter, Carlos García Mac Gaw addresses the case of the Roman late Republic and the Empire, complementing it with references to the Brazilian Northeast and the American South during the nineteenth century. In the third chapter, Carlos Astarita analyses documents of the Roman-Germanic kingdoms as well as Castile and León between the ninth and eleventh centuries, adding comparative references to nomadic pastoral societies, ancient eastern societies, primitive Germanic societies and Latin America during the eighteenth century. In the fourth chapter Chris Wickham refers to Iceland and Norway in the eleventh and twelfth centuries; in the fifth chapter Laura da Graca analyses documents from Northern Spain during the eleventh and twelfth centuries, providing also secondary references to tenth century Iceland; the sixth chapter written by John Haldon cites cases from Southern India from the fourteenth through the seventeenth centuries, and from medieval Christendom, Islam, and Byzantium during the eleventh and twelfth centuries; in the seventh chapter, Octavio Colombo works from Castilian evidence dating from the later Middle Ages.

The studies address historical problems that involve different modes of production:

In the first chapter, Andrea Zingarelli addresses the functioning of the ancient Egyptian state, whose most evident political form is the centralising 
monarchy, and acknowledges the persistence of the state in pharaonic history. Zingarelli analyses the manifestations of statehood that can be found in different settings, and the difficulty in finding spaces in which the state has not left its mark. Thus, the author acknowledges that in the Asiatic mode of production this all-encompassing unit appears as a superior and effective proprietor who appropriates the work of the individuals who are assigned plots in lands owned by the state and held by the individuals as tenants and/or in the lands of village communities. The greater part of surplus labour belongs to the state in the form of taxes and compulsory corvée. This appears as the dominant form into which the power to exploit and dominate the social whole is articulated, also allowing for its reproduction. The state supports the bureaucratic class, who in turn derives the possibility of accumulation and some prestige from its articulation with state institutions. The author concludes that the Egyptian state, considered as a redistributive state, rejects accumulation by an elite of privileged officials and craftsmen while at the same time enabling said accumulation as a side effect of its functioning. In line with the previous argument, the author verifies that private acquisition of land occurred since the earliest times of pharaonic history, although it is often juxtaposed to royal lands, temples or funerary foundations and it generally appears as a donation from the king or a village/city. It is undeniable, however, that certain individuals could manage certain properties, which indicates the presence of forms that coexisted with the extractive mechanism that prevailed especially during the New Empire. The author also detects differentiated forms of extraction in the quasi-slaves - who were acquired mainly in the course of wars of conquest within the framework of the exploitation of lands most often linked to the temple. Zingarelli concludes that these social changes did not replace previous forms but rather created new forms of bondage. Thus, in the author's view the relations of production that correspond to other modes of production coexist with the dominant mode.

In the second chapter, Carlos García Mac Gaw addresses the question of whether it is accurate to characterise the whole of the Roman economy, its dominant class and even the form of exploitation of the villa as slave-based. He notes that the studies of ancient slavery have used the modern system of the plantation as a frame of reference, which leads him to establish comparisons that take into account the specific historical context of the systems under study. The slave-based character of Roman society has been grounded on the proportion of slaves with respect to the general population and the idea that slave labour provided the nucleus of the income of the dominant class; García Mac Gaw suggests that the larger portion of the product of the Roman Empire came from peasant labour, that the colonate was the more widespread form of 
labour exploitation in large holdings, and that we can only assert the primacy of the benefit derived from slavery in the income of the landowning class if we consider the income originated in Italy and Sicily as more important than the income originated in the rest of the provinces. With respect to the exploitation of slaves, the author posits the existence of not one but several forms of surplus appropriation, paying special attention to the situation of the servus quasi colonus, whom the jurists tend to equate with the colonus when addressing questions of their relationship with land and working tools. In disagreement with the minimalist view by which the figure of the servus quasi colonus would be limited to the higher stratum of more qualified slaves, García Mac Gaw suggests that the spread of the institution points to a general trend toward indirect exploitation originating in the period of the Late Republic. The sheer variety of forms of exploitation of slaves (domestic, under direct supervision, through rent, through leases by the owner, etc.) questions the concept of slave mode of production as it implies different ways of linking producers with the means of production and therefore different forms of surplus extraction, among which the plantation is the only one reflecting a singular mode. Lastly, the author considers American slave systems that were subordinated to central capitalism; it is this link - instead of the plantation system - that serves the purposes of comparison. For García Mac Gaw, the articulation with other systems is a general characteristic of slavery, and slave exploitation in the ancient world must be considered within the larger framework of the ancient tributary mode of production, whose dynamics of expansion favour the accumulation explained by the villa; that is to say, slavery in its varied formats was a response oriented to the exploitation of these properties while at the same time it served to reinforce the position of the dominant class with regard to the control of the state apparatus; such would be, in the author's view, the role of slavery as a feature of the dominant class.

In opposition to Adam Smith's view that the emergence of trades was a product of the natural evolution of the division of labour, in the third chapter Carlos Astarita explains the origin of the medieval craftsman based on the relations of production and productive forces. Astarita argues that craftsmanship implies a set of qualities that can only be deployed under certain conditions, and that these conditions were provided by the peasant household within the framework of the social structures that developed in the period between the dissolution of the ancient state and the widespread establishment of the banal lordship. Astarita traces the origin of trade specialisation to the consumption needs of the aristocracy of the early medieval period, who resort to the instruction of domestic slaves to compensate for the shortage of dependent labour (the case of the visigothic aristocracy is an example); this leads to the config- 
uration of a servile segment of craft-producers (blacksmiths, carpenters, etc.) that is differentiated from the rural slaves. The weak social control favours the flight of slaves, many of whom are craftsmen who find it possible to settle in villages and boroughs by joining peasant households as dependents, and after 800 by becoming casati within the framework of the estates. Seigneurial policy favours this incorporation by encouraging in many cases the settlement of slaves, which stimulates the integration and social promotion of the fugitives, unlike what happens in other societies where the fugitive slave becomes marginalised. This shift of the specialised slave from the seigneurial house to the tenure implies conditions that are favourable to an increase in labour productivity, which results from the rent demands of the lord, especially for finished goods; on the other hand, being a private undertaking, the peasant household promotes concentration and the preservation of the family trade; the exploitation of labour by the family provides a model of coercion that favours learning and anticipates the authority of the master craftsman, while deploying at the same time a form of adaptation to the changing needs of the family cycle (incorporation of servants, etc.) that leads to the employment of wage earners, which in turn implies the potential for producing exchange values in the case of tenures that manufacture goods. The servile craftsman fits in with the village household, yet he is distinct from it: the teleological nature of his activity distinguishes the craftsman from the peasant, whose work blends with that of nature and is a source of social recognition that bestows on the craftsman a superior status contradicting his legal condition, cements his self-esteem and promotes the fixation and transmission of the knowledge, as opposed to slaves confined to special environments where the diffusion of the trade is limited by the lack of socialisation. Lastly, the fixation of land property and the individual exploitation in plots of land divided for petty cultivation are assumptions of the argument, which means that the centrality of the domestic unit in the development of trades is circumscribed to the modes of production and social formations based on the individual appropriation of the conditions of production (Germanic mode, peasant-based societies, feudal mode).

In the fourth chapter, Chris Wickham discusses how political power operates in peasant-based societies and the problem of its transformation. He analyses the cases of Iceland and Norway during the eleventh and twelfth centuries, as they are known through the 'family sagas' and 'the kings' sagas' of the thirteenth century. Dissenting from the tradition, reinforced by advocates of the linguistic turn, that denies the historical value of those narratives, Wickham argues for the plausibility of the picture emerging from the sagas, given that it was plausible to the audiences of the thirteenth century, whose society was not all that different from that of their predecessors who are the objects of the 
narrative. Both Iceland and Norway must be understood as social formations in which the peasant mode and the feudal mode coexist, with a dominance of the former. The trend toward the dominance of the feudal mode begins in Norway, where tenancy is more developed, but it is insufficient to imprint changes in political practices, which will occur at a much later time; during the thirteenth century, both societies are still dominated by the peasant mode in view of the fact that the aristocracy, despite having acquired some stability, still has to negotiate with the free people. Wickham analyses the actions of two prominent figures of eleventh century Norway whom Snorri Sturluson refers to in his Heimskringla. They are royal retainers who wield enormous political influence in the royal entourage and have sizeable convening power in the regions they dominate, but are nonetheless known as bœendr, that is to say, free peasants, and owe their position to their personal performance or their allodial bases rather than to royal favour; the examples confirm that the elites of the eleventh century, and those of the thirteenth century who described them, accepted as normal the existence of peasant leaders. The analysis of their degree of wealth reveals it was not substantial; in Iceland few of them own more than one farm, and in Norway, although aristocrats use dependants in the exploitation of their lands, they must allocate political and material resources to obtaining support among the free peasantry, and it is the success or failure of this undertaking, rather than wealth itself, that the sagas take into account when assessing the qualities of the leaders. The possessions of prominent figures are often based on the direct exploitation of domestic dependents, which indicates the presence of the slave mode under the dominance of the peasant mode, given that the wealth generated is allocated to reciprocity expenses to build clienteles; in turn, this form of labour exploitation is limited to medium-sized farms whose proprietors share living quarters with the servants they employ and are not removed from productive chores. The slave form tends to disappear as the feudal mode makes inroads in the form of tenures; lastly, the advance of this mode of production will depend on the concentration of lands by the aristocracy and on the priority its members assign to that task.

In the fifth chapter, Laura da Graca systematises Wickham's concept of peasant mode. Da Graca notes that while some traits of the productive forces and the relations of production are consistent with those of other modes proposed for 'primitive' societies, the form of property corresponds to the Germanic mode as put forth in the Formen, which implies that this is the aspect that gives the mode of production its singularity; she also remarks that the peasant mode combines an evolutionary trend toward inequality, which is inherent to individual appropriation, with the limitations imposed by a social functioning based on reciprocity between households. Da Graca analyses the evolution of 
clientelar relations between aristocrats and free peasants in a social formation dominated by feudalism (Northern Spain during the eleventh and twelfth centuries) with a view to establishing the transformation of those relations into relations of exploitation or relations of feudal vassalage, a process by which the feudal expansion over free spaces is achieved. The persistence of enclaves where the peasant mode is manifest explains why feudal aristocracy resorts to the ideology of reciprocity and the formal preservation of peasant practices as a mechanism for the construction of relations of exploitation; the condition of possibility for said relations of exploitation is the widespread existence of individual private property, which is a feature both of the Spanish villages analysed and of the society described in the Icelandic sagas that the author uses for the analysis of social practice. In that regard, da Graca discusses land endowments in exchange for military services and fosterage, the role of patrons as mediators, the election of a chief by the clients and hospitality; these practices tend to be placed at the service of the reproduction of feudal relations. This happens in two stages: one marked by the prominence of the peasant, a formal respect of customs and the ambivalence of the aristocratic role, then another stage in which the full subordination to the feudal mode has been achieved, as reflected in the transformation of voluntary donations into agrarian rents and their forceful imposition on communities, a process that is consistent with the separation of milites from labourers, the loss of autonomy on the part of the clients and the stabilisation of the relations between aristocrats and free people. The original contents of the primitive practice favour the mutation of functional power into the power to exploit: the practice of repaying mediation services with land becomes functional to the absorption of properties; the indissoluble quality of the fosterage bond enables the restriction of a client's ability to change allegiances, etc.; this shift is supported by a property structure that promotes the spread of transactions involving land. Da Graca shows that the peasant mode, for which she proposes the name of allodial mode of production, has its own dynamic of transformation.

In the sixth chapter, John Haldon addresses the problem of the link between agency and structure. Questioning the treatment of this problem in analytical Marxism, methodological individualism and structuralism, Haldon discusses the role of ideology in the explanation of historical change and its relationship with the conceptualisation of a mode of production, which he understands as an ideal type from which a dynamic cannot be predicated; the institutional forms are what determine the concrete manner in which historical change occurs. Given that in pre-capitalist societies there is a dominance of non-economic aspects such as politics, kinship and religion, Haldon proposes as a metaphor of the whole the idea of an organism whose skeleton (relations 
of production) determines a basic configuration, but in which all the elements are vital to the physiognomy and the evolution of the social body, and that they relate dialectically to one another. One of these elements is ideology, to which Haldon assigns a structuring role in social action: individuals are both agents and carriers of the structures they reproduce through social practice, whose contours are defined by the symbolic universe of which they are a part. Haldon takes W.G. Runciman's model with its categories of 'culture' and 'structure', which correspond respectively to the planes of conscience and the objective situation of the actors depending on their role; both dimensions converge in social practice. Haldon argues that ideology affects the praxis on which social reproduction depends, and this is why it has a pre-eminent role in explaining preservation or transformation in a society. This can occur through 'ritual incorporation or penetration'. Ritual penetration is apparent in cases where the belief system legitimises surplus extraction and determines its distribution (for example, India from the fourteenth to the seventeenth centuries or pre-Columbian societies), or in systems where, even without becoming assimilated with the relations of production, the belief system is inseparable from central aspects such as the transmission of property, the system of kinship, the legitimation of authority, etc. (as in the case of Christianity in the Byzantine world); another form of ritual incorporation is conversion, which functions as an instrument of domination and political integration, as in medieval Christendom or Islam. With respect to the problem of ritual incorporation, it is relevant to determine elite investments, which reveal the importance attributed to the belief system. Another example of the link of causation between economic and cultural elements is the underdevelopment of the mercantile elite in Byzantium during the eleventh and twelfth centuries - in sharp contrast with the prosperity of Italian cities - which could be explained in large part by the fact that the elites, even in the context of the period's mercantile development, consider this activity culturally irrelevant.

In the seventh chapter, Octavio Colombo analyses the functioning of the law of value in pre-capitalist markets drawing from the empirical study of local markets in Castile during the later Middle Ages. The author reviews two diverging perspectives: one supporting the idea that exchange is governed by the law of value where commodity production occurs, and another advocating that the law of value can only function fully under the capitalist mode of production. The first perspective assigns pre-eminence to the labour time embodied in the commodity as the substance of value; the second one views value largely as a social form. Colombo questions the arguments that defend the validity of the law of value in a pre-capitalist context; in his view, this law is better understood in a qualitative sense, as a mechanism for the proportional distribution 
of labour in order to fulfil social needs; this presupposes a process of capital valorisation in the context of inter-capitalist competition, which objectively leads to the tendential adaptation of prices to values. Colombo argues that the commodity as a social form is not identical to its determinations, and therefore does not imply the functioning of the law of value. Given that simple commodity production only exists as a subordinate form within the framework of a dominant mode of production, Colombo discusses the problem in the context of the social relations and productive forces within which exchange occurs. In this respect, he notes that the fluctuations in agrarian production and labour productivity are prominent features of the peasant economy and that these features affect both the secondary sector and prices, which indicates that production is not adapted to social needs and that there is no economic mechanism to regulate the social distribution of labour. These features explain the existence of extra-economic mechanisms such as price fixing by the authorities and other forms of intervention. Confronted with the idea that the notion of 'just price' could imply a certain perception of equivalence, the author poses the question of whether the subjective perception of labour as abstract labour is possible given that the peasant does not conceive of work as a productive activity and that, in the case of the craftsman, the perception of worth attached to the trade makes it difficult to abstract its concrete qualities. In the author's view, the actual viability of labour mobility is relative, and with regard to haggling he argues that its widespread use evidences the existence of particular prices for each transaction that are determined by the negotiating power of the parties, and that in turn this negotiating power depends on factors such as taxation pressure that lead to the acceptance of disadvantageous conditions; on the other hand, even if the approximation of price and value may sometimes be achieved through haggling, the equivalence has to be tendential in order to posit the full functioning of the law of value. Lastly, Colombo considers a number of speculative trade practices that further distort the adaptation to value and enable accumulation processes on the part of wealthier peasants, indicating that the non-functioning of the law of value favours the formation of village capital, which in turn magnifies the inequivalence of exchange as it undergoes the process of valorisation.

In summary, although the different contributions address a variety of historical problems from distinct or even opposing theoretical and methodological standpoints, their shared thrust is the attempt to analyse societies and the problems posed by the historical process understood in terms of modes of production. That notion is at the heart of this work. As is apparent, we have not aimed for a cohesive perspective but, quite to the contrary, we have attempted to discuss a number of problems inherent to pre-capitalist modes of produc- 
tion. We are grateful to the authors who have participated and expressed an interest in contributing to this goal even when they do not share some of our perspectives. It is also pertinent to state that the views expressed in this introduction are our own, and that the other authors do not necessarily share the interpretations and opinions expressed herein. 